UDC 811.113 .5

Sofija A. Bilandžija

University of Belgrade

\title{
A CONTRIBUTION TO THE SEMANTIC SUBCLASSIFICATION OF CAUSATIVE CONSTRUCTIONS IN CONTEMPORARY NORWEGIAN: EFFECTIVE CAUSATION
}

For citation: Bilandžija S.A. A contribution to the semantic subclassification of causative constructions in contemporary Norwegian: Effective causation. Scandinavian Philology, 2018, vol. 16, issue 2, pp. 308-322. https://doi.org/ 10.21638/11701/spbu21.2018.208

In this article the author proposes a subclassification of causative semantic types in contemporary Norwegian, as expressed by the analytic causative constructions with the auxiliary verbs få and gjøre within the framework of prototype semantics. The focus of the article is one the so-called effective causation, such as Mosjon gjør hunden sliten, Mari fikk voksne menn til å gråte or Kjendiser gjør meg svett $i$ hendene. The author analyzes its position among other proposed instances of indirect causation in Norwegian, characterized by the semantic features of the participants (here: the Causer and the Causee), their relationship in regards to the degree of involvement in the causative event and degree of control. The author establishes four subtypes of the effective causation based on the feature of animateness, and claims that the main criterial features of the effective causation are (1) the low degree of Causer involvement, where one cannot postulate any obligatory volitional activity, and the Causer is perceived as a circumstance, reason or a stimulus, (2) the affectedness of the Causee, which shares more features with the roles of Patient or Experiencer, rather than the (affected) Agent, and (3) the type of causing event, or the result, is construed as a spontaneous state or event the Causee undergoes, and is beyond its control (mainly expressed by verbs and adjectives denoting automatic responses). The construction type is thus always the intransitive analytic causative.

Keywords: Norwegian, effective causation, causative construction, analytic causative, semantics, Prototype Theory, indirect causation, participant structure, Causer, Causee, result. 


\section{INTRODUCTION}

This paper deals with the qualitative analysis of one semantic subtype of external factitive causation expressed by analytic causatives in contemporary Norwegian, based on the extensive research on Norwegian causative constructions and their semantics [Bilandžija, 2014]. The research was conducted within the main framework of Prototype Theory, and the examples stem from the NoWac-corpus, extracted during previous research on all the semantic subtypes (2013/14).

The main approach within the research on causative semantics has been the analysis of various types of causation, $f$. ex. factitive or permissive, direct or indirect, benefactive, etc. Although the majority of authors accept the difference between direct and indirect causation, there is no concensus on further subcategorization of these semantic types, especially taking into consideration the fact that the subtypes are language-specific.

\section{PRELIMINARIES}

This chapter will define some of the terminology used in the research on causatives and briefly outline the characteristics of the participant structure, necessary for understanding the subclassification suggested here.

The expression of causality in language ${ }^{1}$ can be seen as a relationship that holds between two events, with an obligatory determination that one leads to the other. It is thus construed as a complex causative event, a macroevent, that comprises of at least two subevents or microevents connected by the relation of causation [Nedjalkov, Sil'nickij, 1969a, p. 5; Shibatani, 1976, p. 239; Frawley, 1992, p. 161; Wolff, 2003, p. 3]. The first subevent is the causing event $\left(\mathbf{E}_{1}\right)$, representing the predication of cause, while the second event is the caused event $\left(\mathbf{E}_{2}\right)$, representing the result the causing event has led to. The prototypical causative event is traditionally defined as the agentive causal chain, i.e. the prototypical transitive event based on the maximum contrast principle. This means that it's

${ }^{1}$ In this paper the term causality is used to denote the relationship that holds between cause and effect in the world, and the term causativity as the expression of causal relationships within a given language, or a conceptualization of an event as it is expressed in a language. The term causation is used a term that denotes a relationship between cause and effect. 
construed as an event with at least two separate participants, one being the volitive Agent acting conciously and intentionally, directing its activity towards the Patient, whose change in (physical) state completes the causative event [Croft, 1991, p. 155; Croft, 1998, p. 89; Rawoens, 2007, p. 88; Hopper, Thompson, 1980, p. 252; Næss, 2006, p. 318; Næss, 2007, p. 29].

Languages have on their disposal a complex system of productive and less productive formal markers which encode different subevents of the causative macroevent, and they are usually called either causative constructions (CC) or causatives. For this purpose we adhere to the well established distinction between analytic, morphological and lexical causatives [cf. Comrie, 1989, pp. 167-168; Kulikov, 2001, p. 886-887]. The analytic causative in question is a complex CC with a VP in which the notion of causation is expressed by auxiliary causative verbs $f a$ ('get') or gjøre ('do'), and $\mathrm{E}_{2}$ is encoded as obligatory argument within the same predicate (more on the author's understanding of analytic CC in Norwegian in [Bilandžija, 2013, p. 4]):

(1) Politiet fikk dem til å dempe seg. 'The police got them to keep the noise down'

(2) Mosjon gjør hunden sliten. 'Exercise makes the dog tired'

The semantic subtypes are usually defined based on the paticipant's animateness and the nature of of the relationship that holds between the participants, e.g. their strength or the degree of control that the Causer and the Patient or the Causee maintain. In this paper the term Causer is used broadly, to denote any type of participant encoded as the primary cause that initiates the activity expressed by a causative verb. We consider the component of instigation of the action (leading to a perceptible change of state in another participant) to be the criterial feature of the Causer participant. Although the the prototypical Agent is considered to be the instance of the prototypical Causer, we have established that its features of sentience, capability of volitive planning and deliberate instigating are not the features licenced by the majority of causative verbs. That is why also less prototypical agents can be construed as instigators of certain actions: natural forces, inanimate entities, situational and eventive agents, as well as generalized impersonal causers.

The Causee is the second participant role crucial for the semantic analysis of the analytic CCs. The Causer is the encoded as the instigator 
of the action and surfaces as the syntactic subject of the CC, while the Causee is the Agent of the caused subevent, and the the event is considered to be mediated [Ackerman, Moore, 1999, p. 2; Stefanowitsch, 2001, p. 36; Loewenthal, 2003, p. 97; Mathieu-Reeves, 2006, p. 95]. The Causee in Norwegian is syntactically encoded as the object, irrespectably of whether the caused event is transitive (ex. 3) or intransitive (ex. 4) (for the terms transitive/intransitive causative cf. [Kemmer, Verhagen, 1994, p. 63; Verhagen, Kemmer, 1997, p. 62]):

(3) Mari fikk fikk voksne menn til å gråte. 'Mari made the grown men cry'

(4) Hun fikk ham til å sende vekk sine barn. 'She got him to send his children away'

In a prototypical mediated causative event the Causer and the Causee are two conceptually, semantically and formally distinct participants. As the Causee doesn't initiate the action, it can exhibit a certain degree of lack of control in performing the resulting effect, and it can be more or less affected - all of this plays a significant role in determining the semantics of a CC. Norwegian data shows that both animate and inanimate entities can assume the Causee role.

\section{(IN)DIRECT CAUSATION AND THE ANALYTIC CASUATIVE IN NORWEGIAN}

The terms direct and indirect causation [Frawley, 1992; Shibatani, Pardeshi, 2001; Loewenthal, 2003; Stefanowitsch, 2001] are at the core of the research on causative semantics, and are closely related but not equal to the terms such as manipulative and directive causation [Shibatani, 1976, pp. 31-38], direct and mediated causation [Givón, 1975, p. 6568], as well as contact and distant causation [Nedjalkov, Sil'nickij, 1969b, p. 28], which all profile different aspects that may influence the notion of (in)directness of influence that one participant has on the other.

Direct causation entails a causative event where the Causer is the only source of energy an this type is linked to the prototypical causative situation. The performance of the activity depends solely on the causer, and usually entails a spatio-temporal overlap between $\mathrm{E}_{1}$ and $\mathrm{E}_{2}$. Indirect causation entails a causative event in which the Causer does not perform the activity from the beginning to end, and $E_{2}$ is performed by another entity or process which is the immediate source of energy for the 
accomplishment of the result (cf. [Kemmer, Verhagen 1994, p. 120; Verhagen, Kemmer, 1997, p. 67; Shibatani, Pardeshi, 2001, p. 139-140; Stefanowitsch, 2001, p. 263; Wolff, 2003, p. 4; Rawoens, 2007, p. 88-89])2.

One approach, based on the characteristics if $E_{1}$ and the semantics of the causative verb has appeared in several influental works on causative semantics [Kemmer, Verhagen, 1994; Verhagen, Kemmer, 1997; Talmy, 2000]. Our approach to the semantic subcategorization has been influenced primarily by the approaches used by Croft and Wierzbicka [Croft, 1991, p. 167-168; Wierzbicka, 1998]. Other classifications, grounded in the semantic distinctions within English auxilliary causative verbs were less adequate, as the Norwegian auxilliary causatives få and gjøre, expressing a broad spectrum of causal relations are not sensitive to the same semantic restrictions as the English auxilliaries make, have, get or cause. The Norwegian analytic causative is a highly grammaticalized construction, and one form encodes a wider variety of different causation types, spanning from direct physical causation through different subtypes of indirect causation such as indirect physical causation, persuasion, enabling or just a presence leading to a reaction.

This paper uses result type expressed in $E_{2}$ as the main criterium for differentiation of five main causation types in Norwegian. Besides effective causation, we distinguish among (1) inducive causation, which requires an animate Causee, and the result is always an activity performed by the Causee. It's a frequent semantic subtype, comprising of several further instances of coercive, manipulative and motivational causation (e.g. Jeg fikk henne til å smake på grøten 'I got/made/had her taste the porridge'), (2) affective causation, which expresses the triggering of psychological, mental and emotional reactions of the Causee (e.g. Jobben jeg er $i$ i dag gjør meg veldig deprimert 'My current job makes me depressed'), (3) evaluative causation, which incorporates a subjective evaluation (e.g. Disse buksene gjør meg tykk 'These trousers make me (look) fat'), (4) intrapersonal causation, which is semantically and formally marked as less prototypical as it expresses the causation where the Causer/Causee are one and the same participant (e.g. Det var først

${ }^{2}$ It's been noted that there is a certain degree of correlation between the structural type of a CC and the degree of the directness of causation (a correlation between lingustic form and conceptual structure), thus making the causation typically indirect when the expression is analytic and/or polymorphemic (cf. Shibatani, 1976, pp. 31-33; Frawley, 1992, p. 164; Shibatani, Pardeshi, 2001, p. 91ff). 
nå at jeg fikk meg til å gjøre det 'It was only then that I made myself do that'). We can finally also distinguish benefactive causation, prototypically encoded by a different CC, the so-called 'fä-passive', with an overtly unexpressed Causee, but retaining it in the semantic structure (Jeg fikk vaksinert valpene 'I had the puppies vaccinated').

\section{EFFECTIVE CAUSATION}

By effective causation we understand the type of causation where the $\mathrm{E}_{2}$ indicates an event or a state conceptualized as a spontaneous result, and can be illustrated by the following formula:

\section{NP1 [+/-Anim] CAUS NP2 [+/-Anim] VPInf/AP [Event/State]}

The common denominator for all subtypes is the fact that the result is to be perceived as an spontaneous effect, and that the Causee goes through the action unwillingly or is in a state that is beyond its control. The predication of $\mathrm{E}_{2}$ can be conceptualized either as an event or a state:

(5a) Saltet får isen til å smelte. 'Salt makes ice melt'

(5b) Allergitablettene gjør meg søvnig. 'The allergy pills make me sleepy'

The events are formally expressed either as infinitive phrases after the verb fa (ex. 5a), while the states are typically expressed as AP object predicatives after the verb gjøre (ex. 5b), although there are a few instances where the verb within the infinitive phrase denotes a state:

(6a) Hvordan fikk de dem [pommes fritesen] til å smake akkurat som Grippos? 'How did they get them [fries] to taste exactly the same as Grippos?'

(6b) Hvis alle husstander i Norge hadde fått PC-en sin til å vare ett år lenger, ville man spart mye mer energi. 'If all the households in Norway got their PCs to last an extra year, one would save much more energy'

We can further distinguish four subtypes of effective causation in regards to the animateness criterium: effective interpersonal causation, 
effective non-volitive causation, effective volitive causation and effective impersonal causation.

\section{EFFECTIVE INTERPERSONAL CAUSATION}

Effective interpersonal causation is a slightly less prototypical type of interaction between to animate participants, and can be illustrated by the following formula:

\section{NP1 [+Anim] CAUS NP2 [+Anim] VPInf/AP [Event/State]}

The animate participant in the Causer role, predominantly human beeing, doesn't act with volition and intention, but is rather conceptualized as a participant within a circumstance that accidentally leads to a result. This kind of Causer can be characterized as a causative stimulus that causes a physiological reaction of another animate participant. One can rather interpret it as a situation, a circumstance or a trait whose sole presence spurs a change of state, and the potential to realize the change of state lies within the Causee, which is affected and shows semantic traits of a patient-experiencer type of participant:

(7a) Gervais fikk kjendisene til å gispe. 'Gervais made celebrities yawn'

(7b) Ronaldo fikk tilskuer til å blø neseblod. 'Ronaldo made a spectator bleed from his nose'

(7c) Kun når eier lå i samme rom fikk hunden til å sove i lengre perioder. 'Only the owner's presence in the same room made the dog sleep for longer periods of time'

(7d) Er det noe jeg trenger for å få god karakter i matte, er det ikke en gammel og kjedelig matteloerer som gjør meg søvnig. 'If there's anything I need in order to get a good math grade, it's not an old and boring teacher who makes me sleepy'

In these examples one cannot attribute the Causer any volitional planning or execution of an event. The material shows that the causative stimulus here appears in the form of less prototypical Agents, such as non-volitional Agent $(7 a, b, d)$ or eventive causers of the type 'Agent's activity' (7c). 
The Causee is here of the patientive type (the fä-constructions) or a Patient (the gjøre-constructions). This not accidental, because although in the taxonomic class of a human being, the Causee is the agentive participant with the lowest degree of agentivity since it's completely non-volitional, has no control over the process and is totally affected. It is the last participant in the causative chain and marks the completion of the event, and the effective causation expressed by the fä-construction can only be realised as intransitive causative. The material shows that the predication of result comprises of verbs and adjectives that denote non-volitional activities and states of human beings: få noen til å rødme / skjelve / rape / tisse / sove / falle / hoste / gjespe / blø ('make smb. blush / shake / burp / pee / sleep / fall / cough / yawn / bleed'), gjøre noen svett / søvnig / gravid / sliten / kvalm / mo i knorne ('make smb. sweaty / sleepy / pregnant / exhausted / sick / weak at the knees').

The cause can be in the realm of the same participant, and in this case the reaction appears spontaneously during Causer's activity:

(8) Det å gå opp trappa får meg til å hoste. 'Walking up the stairs makes me cough'

\section{EFFECTIVE NON-VOLITIVE CAUSATION}

The effective non-volitive causation resembles the previous subtype in that it denotes the causation of a process or a state of an animate participant, but in this instance by an inanimate entity, and can be represented as follows:

\section{NP1 [-Anim] CAUS NP2 [+Anim] NPInf/AP [Event/State]}

We can certainly not ascribe any sentience, volition or a motor program with which it can effect the Causee, which makes it a less prototypical Causer, covering the participant classes of forces or potents (e.g. kulde 'cold', varme 'warmth', hete 'heat', sol 'sun', smerte 'pain'), inanimate entities (e.g. røyk 'smoke', tabletter 'pills', en kule i ryggraden 'a bullet in the spine'), eventive participants of the type 'circumstance' and 'activity' (e.c. aerobic, yoga, en time på sykkelen 'one hour on the bike', samleie 'intercourse', all den utspioneringen og snakkingen om fiendene 'all that 
spying and talking about the enemies', det å få e-post 'getting e-mails') or the stimulus (e.g. lukten av kloroform 'smell of chlorophorm', aroma). The Causer class comprizes of a relatively stable group of causers within one and the same participant, such as body parts, bodily functions or other processes that develop internally within the Causer:

(9a) Jeg tror ikke det er blodtrykket som gjør meg svimmel. 'I don't think it's the blood pressure that makes me dizzy'

(9b) Et hormon som ble sprøytet inn fikk sauen til å miste all ulla. 'A hormon it was injected with made the sheep lose all its fleece'

(9c) Sekretet som renner til svelget, kan få barnet til å hoste. 'A secretion flowing down to the pharynx can make a child cough'

(9d) Lungene mine får meg til å hoste opp slim. 'My lungs are making me cough up phlegm'

Also these inanimate Causers provoke various spontaneous processes, physiological reactions and the states of the Causee: $f \stackrel{\circ}{n}$ noen til å rape / hoste / rynke øyenbrynene / rødme / skjelve ('make smb. burp / cough / furrow one's eyebrows / blush / tremble'), gjøre noen sliten / svett / andpusten / trett / lam / syk / svimmel / varm ('make smb. tired / sweaty / out of breath / paralyzed / ill / dizzy / warm').

\section{EFFECTIVE VOLITIVE CAUSATION}

Effective volitive causation encompasses those cases where the animate Causer leads to a change of state in an inanimate patientive Causee, and is illustrated as follows:

\section{NP1 [+Anim] CAUS NP2 [-Anim] VPInf [Event/State]}

The examples illustrating this type of causation are relatively few in the corpus material, which can be expected. The causation type where an animate participant exerts an influence upon a patient or another highly affected participant exemplifies a prototypical physical manipulative causation that is usually encoded as direct, and usually by a syntetic causative (Ungen har knust rute på skolen 'The kid has broken a win- 
dow at school'), or can be construed as a coercive indirect causation. The effective volitive causation refers primarily to those instances where the Causer, in the taxonomic class of a human being, influences a Causee with a sertain degree of autonomy, predominantly machines or other inanimate entities that have their own energy:

(10a) Ivrige bokkjøpere fikk a-ha-nettsiden til å krasje. 'Eager book buyers made the A-ha site crash'

(10b) Vi fikk fjernkontrollen til å fungere igjen på en eller annen merkelig grunn. 'Strangely, we got the remote working again'

(10c) Slik får du vaskemaskinen til å vare lengst mulig. 'This is how you can make your washing machine last as long as possible'

We can observe in the corpus that the causation is predominantly construed as getting an entity to perform a certain task or end in a state beneficial to the Causer. The causation can be intentional (10c) or intentional/accidental (10a).

\section{EFFECTIVE IMPERSONAL CAUSATION}

The fourth and final subtype is what we call the effective impersonal causation, represented as follows:

NP1 [-Anim] CAUS NP2 [-Anim] VPInf [Event]

This subtype is represented by numerous examples in the corpus material, and is the type in which a inanimate Causer leads to a change of state or instigates a process that another inanimate participant goes through.

All less prototypical, inanimate agents surface as Causers, such as forces (11a), all instances of inanimate participants such as objects, machines, medications (11b, c and e), as well as circumstances (11d) or generalized causers (11f):

(11a) Bølgen fikk båten til a kantre. 'The wave made the boat flip'

(11b) Persienner fikk ruten til å sprekke. "Venetian blinds made the window break' 
(11c) Et kjøleanlegg som holder syv-åtte minusgrader får isen til å fryse ekstra fort. 'A cooler with constant minus seven-eight degrees makes the ice melt really fast'

(11d) Det bleke måneskinnet fikk elva til å glitre. 'The pale moonshine made the river sparkle'

(11e) Kortisontabletter får sykdommen til å gå tilbake. 'Cortisone pills make the illness recede $0 \mathrm{~T}$

(11f) I august er det mer fuktighet i lufta. Det får maten til å råtne og mugne fortere. 'There is more humidity in August. It makes the food rot and mold faster'

In these constructions the Causees are predominantly patient-like, and have no control over the process they are going through. The corpus material shows that the predication of result appears mostly in the infinitive VP constructions in intransitive causatives. Semantic subclassification shows that this subtype encompasses certain decausative verbs (sprekke 'burst', fryse 'freeze', spres 'spread', koke 'boil'), but predominantly typical intransitive verbs as the verbs-of-internal-causation (råtne 'rot', mugne 'mold', visne 'wilt'), verbs of motion (kantre 'capsize', forsvinne 'disappear', gå tilbake 'retreat', vibrere 'vibrate', skli 'slide', slå/banke 'pound (of a heart)', stige 'rise', riste 'shake') and the verbs of sensory emission (glitre 'glow', stråle 'shine', smake 'taste', lukte 'smell', smelle 'slam').

\section{CONCLUSION}

Effective causation is one semantic subtype expressed by Norwegian analytic causative constructions. As causative auxiliaries $f a$ and gjøre show high degree of semantic unmarkedness, it allows different types og Agents and agentlike participants surface as their subjects, and the causative constructions express high degree of 'unspecified' indirect causation. Our semantic differentiation is thus based on the predication of the result, which in this case is somewhat less prototypical in that the result is conceptualized as a spontaneous effect, and not the direct consequence of a sentient and volitional Causer acting with deliberation.

The literature on causatives often analyzes Causee participants as animate participants in opposition to the Causer, and as "real" Agents of the caused event, i.e. as the participants that would have surfaced as subjects had the $\mathrm{E}_{2}$ been expressed separately (e.g. Politiet fikk ham 
til a forlate hotellresepsjonen 'The Police got/made him leave the hotel reception' $\rightarrow$ Han forlot hotellresepsjonen 'He left the hotel reception'). In effective causation both animate and inanimate entities can assume the role of the Causee, and their traits show that they can be treated as patientlike participants since they show total lack of control over the process they are affected by, regardless of the Causer's degree of control, which is defocused in this semantic subtype.

An important feature that distinguishes effective causation from inducive causation is the role of the Causer. In inducive causation, which we consider the main and most protoypical instance of indirect causation in Norwegian, the Causer is a conscious instigator of the causal chain, while the degree of control exerted by the Causee varies, and spans from minimal (in the case of coercion) to maximal (causation by verbal instruction). Another feature distinguishing the two subtypes is the result type. Unlike the inducive subtype, the effective causation can be expressed by both auxiliaries, as the results are perceived as events and states beyond the Causees control, and the constructions are considered to be intransitive causatives. On the other hand, the inducive causation type is expressed solely by the $f a$-constructions and the result is always an activity. In transitive analytic causatives, as well as two-personal synthetic causatives, the Causee has a mediator role, and performs the activity initiated by the Causer with more or less resistance, and can be equated with the role of affected Agent. On the other hand, in intransitive analytic causatives, as is the case of effective causation, the Causee shows a higher degree of being affected by the activity, and has more similarity with the role of the Proto-Patient.

Our further research is twofold: it is aimed at finetuning the semantic characteristics of the subtype, as well as exploring the equivalents of the subtype in Serbian, which has no productive grammaticalized analytic CCs, and where we already have noticed a tendency to express the Causee as the benefactor/malefactor and the Causer as a peripheral argument.

\section{REFERENCES}

Ackerman F., Moore J. Syntagmatic and paradigmatic dimensions of causee encodings. Linguistics and Philosophy 22, 1999, pp. 1-44.

Bilandžija S. A. Supkategorizacija verbalnih kauzativnih konstrukcija u norveškom jeziku: analitički kauzativ [Subcategorization of verbal causative constructions 
in Norwegian: Analytic causative]. Komunikacija i kultura online, 4 [Communication and Culture online, 4], 2013, pp. 1-12. (In Serbian)

Bilandžija S. Semantika kauzativnih konstrukcija u norveškom i srpskom jeziku [The Semantics of Causative Constructions in Norwegian and Serbian]. Doktorska disertacija [Doctoral dissertation]. Beograd, Univerzitet u Beogradu, 2014. (In Serbian)

Bilandžija S. A. Benefaktivni kauzativ i norveški $F \AA$-pasiv [Benefactive causative and the Norwegian få-passive]. Anali Filološkog fakulteta XXVII (2) [Annals of the Faculty of Philology XXVII (2)], 2015, pp. 351-367. (In Serbian)

Comrie B. Language universals and linguistic tipology. Syntax and morphology. Chicago, University of Chicago Press, 1989. 264 p.

Croft W. Syntactic Categories and Grammatical Relations. The Cognitive Organization of Information. Chicago, London, The University of Chicago Press, 1991. $331 \mathrm{p}$.

Croft W. The Structure of Events and the Structure of Language. The New Psychology of Language: Cognitive and Functional Approaches to Language Structure, Vol. 1. Ed. M. Tomasello. New Jersey, London, Lawrence Erlbaum Associates, 1998, pp. 67-92.

Frawley W. Linguistic Semantics. New Jersey, London, Lawrence Erlbaum Associates, $1992.533 \mathrm{p}$.

Givón T. Cause and control: on the semantics of interpersonal manipulation. Syntax and Semantics 4. Ed. J. P. Kimball. New York, Academic Press, 1975, pp. 59-89.

Hopper P., Thompson S. A. Transitivity in Grammar and Discourse. Language 56, 1980, pp. 251-299.

Kemmer S., Verhagen A. The grammar of causatives and the conceptual structure of events. Cognitive Linguistics 5/2, 1994, pp. 115-156.

Kulikov L. I. Causatives. Language Typology and Language Universals, Vol. 2. Eds. M. Haspelmath et al. Berlin, New York, Walter de Gruyter, 2001, pp. 886-898.

Loewenthal J. Meaning and use of causeeless causative constructions with laten in Dutch. Usage-Based Approaches to Dutch. Lexicon, grammar, discourse. Eds. A. Verhagen, J. van de Weijer. Utrecht, LOT, 2003, pp. 97-129.

Mathieu-Reeves D. Direct and indirect causation in Sinhala: examining the complexity continuum. Santa Barbara Papers in Linguistics 17, 2006, pp. 95-101.

Næss Å. Case semantics and the agent-patient opposition. Case, Valency and Transitivity. Eds. L. Kulikov et al. Amsterdam, Philadelphia, John Benjamins Publishing Company, 2006, pp. 309-327.

Næss Å. Prototypical Transitivity. Amsterdam, Philadelphia, John Benjamins Publishing Company, 2007. 240 p.

Nedjalkov V.P., Sil'nickij G. G. Tipologiia kauzativnyh konstrukcii [The Typology of causative Constructions]. Tipologiia kauzativnyh konstrukcii. Morfologicheskii kauzativ [The Typology of causative Constructions. Morphological 
Causative]. Ed. A.A.Holodovich. Leningrad, Nauka Publ., 1969a, pp. 5-19. (In Russian)

Nedjalkov V. P., Sil'nickij G. G. Tipologija morfologicheskogo i leksicheskogo kauzativov [The Typology of Morphological and Lexical Causatives]. Tipologiia kauzativnyh konstrukcii. Morfologicheskii kauzativ [The Typology of causative Constructions. Morphological Causative]. Ed. by A. A. Holodovich. Leningrad, Nauka Publ., 1969b, pp. 20-50.

Rawoens G. Kausativa verbkonstruktioner i svenskan och nederländskan. En korpusbaserad syntaktisk-semantisk undersökning. Doctoral dissertation. Gent, Universiteit Gent, 2007.

Shibatani M. Causativisation. Syntax and Semantics 5. Ed. by M. Shibatani. New York, Academic Press, 1976, pp. 239-294.

Shibatani M., Pardeshi P. The Causative Continuum. The Grammar of Causation and Interpersonal Manipulation. Ed. by M. Shibatani. Amsterdam, Philadelphia, John Benjamins Publishing Company, 2001, pp. 85-126.

Stefanowitsch A. Constructing causation: A Construction Grammar Approach to Analytic Causatives. Doctoral dissertation. Houston, Rice University, 2001.

Talmy, L. Toward a cognitive semantics. Vol. II: Typology and Process in Concept Structuring. Cambridge MA, London, MIT Press, 2000. 495 p.

Verhagen A., Kemmer S. Interaction and causation: Causative constructions in modern standard Dutch. Journal of Pragmatics 27, 1997, pp. 61-82.

Wierzbicka A. The Semantics of English Causative Constructions in a Universal-Typological Perspective. The New Psychology of Language: Cognitive and Functional Approaches to Language Structure, vol. 1. Ed. by M. Tomasello. New Jersey, London, Lawrence Erlbaum Associates, 1998, pp. 93-153.

Wolff P. Direct causation in the linguistic coding and individuation of causal events. Cognition 88, 2003, pp. 1-48.

\section{София Биланджия}

Белградский университет

\section{О ВЫДЕЛЕНИИ ПОДКЛАССОВ В СЕМАНТИЧЕСКОМ КЛАССЕ КАУЗАТИВНЫХ КОНСТРУКЦИЙ СО ЗНАЧЕНИЕМ РЕЗУЛЬТАТИВНОЙ КАУЗАЦИИ В СОВРЕМЕННОМ НОРВЕЖСКОМ ЯЗЫКЕ}

Для цитирования: Bilandžija S. A. A contribution to the semantic subclassification of causative constructions in contemporary Norwegian: Effective causation // Скандинавская филология. 2018. Т. 16. Вып. 2. С. 308-322. https://doi.org/ $10.21638 / 11701 /$ spbu21.2018.208

Предлагается разбиение на семантические подклассы аналитических каузативных конструкций современного норвежского языка со вспомогательными глаголами få ‘получать' и gjøre 'делать'. В качестве теоретической базы используется теория прототипов. Основное внимание уделено так называемой результативной каузации, как в предложениях Mosjon gjør hunden sliten, Mari fikk voksne 
menn til å gråte или Kjendiser gjør meg svett $i$ hendene. Автор рассматривает места этой классификации в сравнении с ранее предлагавшимися подходами к изучению непрямой каузации в норвежском языке, дает оценку семантическим характеристикам актантов (здесь: каузатор и каузируемый), а также соотношению между ними в том, что касается степени контроля и степени вовлеченности в каузируемое событие. В рамках результативной каузации автор выделяет четыре подтипа на основании такой черты, как одушевленность, и выдвигает следующие основные признаки результативной каузации: (1) низкая степень вовлеченности каузатора, при которой невозможно постулировать его обязательную целенаправленную активность, так что каузатор воспринимается как сирконстант, причина или стимул; (2) тип воздействия на каузируемого, имеющего больше общих черт с ролями пациенса или экспериенцера, чем с ролью (подвергающегося воздействию) агенса; (3) каузирующее событие, или результат, предстает как спонтанное состояние каузируемого или как событие, которому оно подвергается и которое он не в состоянии контролировать (будучи выраженным главным образом при помощи глаголов и прилагательных, обозначающих автоматическую реакцию на стимул). Таким образом, конструкции этого типа всегда представляют собой непереходный аналитический каузатив.

Ключевые слова: норвежский язык, результативная каузация, каузативная конструкция, аналитический каузатив, семантика, теория прототипов, непрямая каузация, актантная структура, каузатор, каузируемое, результат.

\section{Sofija Bilandžija}

$\mathrm{PhD}$, Assistant Professor, University of Belgrade, Studentski trg 3, 11000 Belgrade, Serbia

E-mail: sofibi75@gmail.com; sofija.bilandzija@fil.bg.ac.rs

Received: August 2, 2018 Accepted: September 27, 2018 